\title{
A framework for integrating flood defence and biodiversity in washlands in England
}

\author{
J. MORRIS and T.M. HESS, Institute of Water and Environment, Cranfield University, Silsoe, Bedfordshire, MK45 4DT. \\ E-mail:j.morris@cranfield.ac.uk
}

D.J.G. GOWING, Department of Biological Sciences, Open University, Walton Hall, Milton Keynes, MK7 6AA

P.B. LEEDS-HARRISON, National Soil Resources Insititute, Cranfield University, Silsoe, Bedfordshire, MK45 4DT

N. BANNISTER and R.M.N. VIVASH, River Restoration Centre, Silsoe Campus, Silsoe, Bedford, MK45 4DT, UK

M. WADE, Ecoscope Applied Ecologists Ltd, Compass Point Business Park, St. Ives, PE27 5JL

\begin{abstract}
Concerns about increased flood risk and loss of biodiversity in lowland areas, coupled with changing priorities in the countryside have drawn attention to the potential contribution that managed washlands can make to improved flood management, habitats and wildlife.

Following a review of research literature, a survey of flood managers and conservation officers, and an evaluation of selected case sites in England, a framework to help integrate potential flood management and biodiversity opportunities was constructed. This framework consists of three components, namely: a Hydraulic classification which categorises washlands according to degree of hydraulic control; a Habitat classification which captures attributes of washland hydrology that define the type of existing or potential habitats; and, a Menu of Interventions to "engineer" or manage particular flooding and soil wetness regimes and thereby better exploit habitat potential. Washlands were also categorised by main type of benefit whether this is flood management, conservation, or in the case of integrated washland, a balance of the two. The advantages of alternative administrative and funding arrangements for washlands, whether land acquisition or annual payment to existing land owners, were also explored.

It was concluded that the classification of washland flooding and water level regimes can help to define habitat potential. It can also help to guide hydraulic engineering and management actions that can be taken to realise this potential. Although there is potential synergy between flooding and biodiversity under some flood regimes, biodiversity benefits mainly depend on the management of water regimes following flood events. There is a clear need to "join up" hitherto fragmented policy and funding mechanisms in order to exploit the potential for washlands to simultaneously deliver flood management and biodiversity benefits.
\end{abstract}

Keywords: Flood defence; biodiversity; washlands; floodplains.

\section{Introduction}

Flood defence for farmland, along with high levels of subsidies, has been an important element of Britain's production oriented agricultural policy. Many floodplain areas have "benefited" from publicly funded flood defence and land drainage schemes that reduced crop damage and facilitated a change to more intensive farming systems [1].

Recently, however, policy has emphasised environmental enhancement, greater diversity of economic activity as a basis for sustainable rural livelihoods, and public enjoyment of the countryside. Funds previously committed to support farm output are increasingly diverted to encourage land managers to deliver environmental benefits [2].

For these reasons, there appears to be reduced justification for high standards of flood defence for agriculture. Indeed, there may be substantial benefits if some floodplain land is returned to its previous unprotected, un-drained condition. In some areas, the positive creation of washland and/or flood storage facilities could provide relief to downstream areas presently subject to unacceptable flooding or reduce the need for expensive flood defence measures elsewhere in the catchment. They could also contribute to the management of scarce fresh water resources, provide wildlife and amenity benefits, and, through credits for flood storage and extensive farming, provide alternative sources of income to land managers [3].

In this context, with funding from the Department for Environment, Food and Rural Affairs (Defra) and English Nature, an attempt was made [4] to determine the scope for simultaneously achieving flood management and biodiversity objectives, and to investigate how this might be achieved in practice through the creation of integrated washlands. The enquiry is set in the context

Received and accepted: 
of a strategic approach to catchment flood management [5], preparation for the implementation of the Water Framework Directive [6] and concerns about possible increases in future flood risk associated with climate change $[7,8]$.

The enquiry involved a review of relevant literature, five case studies of washland sites in England, a questionnaire survey of Flood Managers belonging to the Environment Agency for England and Wales and Conservation Managers of mainly Non-Governmental Conservation Organisations, and a workshop attended by 35 representatives of key stakeholder groups.

This paper focuses on the development of a framework to classify washlands by hydraulic and habitat characteristics which can be used to guide management interventions. It also considers the characteristics of washlands by dominant benefit type and the administrative options that may be used to promote "integrated washlands" where the latter attempt to combine the management of flood risk and the enhancement of biodiversity.

\section{Defining washlands}

The term "washland" can mean different things to different people. The Oxford English Dictionary [9] defines a washland as "land that is periodically flooded by a river or stream". Although the term may refer to land on undefended floodplains over which water "washes" during peak flows, river engineers in particular often regard washland as land which is "managed" for the purpose of storing water [10].

In England, virtually all floodplains are managed in some way, and the retention or restoration of the natural functions of the floodplain also reflect decisions to manage hydrological processes. For this reason, a broad inclusive definition of a washland is used here, namely: "an area of the floodplain that is allowed to flood or is deliberately flooded by a river or stream for flood management purposes, with potential to form a wetland habitat". This includes washlands that are created as a consequence of setback of agricultural defences which previously gave relatively high protection from flooding.

\section{Washland classification based on hydraulic and habitat characteristics}

Washlands take a variety of forms and demonstrate a variety of characteristics $[10,11]$. For management purposes washlands can be classified according to flood regime, soil wetness (once flooding is over), and land use and related habitats. In order to determine the scope for combining flood management and conservation management in practice, these characteristics were built into a two staged approach to classification, supported by a "Menu of Interventions" which can be used to help achieve the desired outcomes. The approach is summarised in Figure 1.

The first stage, referred to as the Hydraulic Classification (Table 1) classifies washlands according to degree of control of flood water inflow and outflow, reflecting a mainly engineering and flood management perspective. Generally, the greater is the degree of engineering intervention, the greater is the degree of control.

From a flood management perspective, washlands can provide additional storage for water upsteam of the river reach where flood control is required by reducing (attenuation) or delaying (translation) flood peaks [12]. Flood engineers often make the distinction between "on-line" and "off-line" storage. Storage may be "on-line" where the floodplain is not separated from the channel and storage may be provided by natural out of bank flow or controlled backing-up behind a constriction on the channel. Rejoining river channels with their natural floodplains is central to the concept of sustainable flood risk management. Alternatively, storage may be "off-line" where it is separated from the main channel by control structures - such as embankment and sluices and flow is diverted into and released from the storage area as required for flood management purposes. Both on-line or off-line storage areas may have potential biodiversity value. Although the classification in Table 1 can accommodate the distinction between off- and on-line measures, it places more emphasis on the degree of overall hydraulic control that can be exerted rather than on the separation of flow and storage functions.

Although it is generally agreed that flood plain washlands reduce or delay floods [13], for a review not all will necessarily

\begin{tabular}{|c|c|c|}
\hline $\begin{array}{l}\text { Hydraulic Classification } \\
\text { Classifies washlands } \\
\text { according to degree of } \\
\text { hydraulic control. Generally } \\
\text { the greater is the degree of } \\
\text { engineering intervention, the } \\
\text { greater the degree of control } \\
\text { with respect to inflow onto the } \\
\text { washland from the source } \\
\text { channel and outflow from the } \\
\text { washland } \\
\text { (see Table 1) }\end{array}$ & $\begin{array}{l}\text { Menu of } \\
\text { Interventions } \\
\text { Interventions to } \\
\text { 'engineer' or } \\
\text { manage particular } \\
\text { flooding and soil } \\
\text { wetness regimes } \\
\text { and thereby better } \\
\text { exploit habitat } \\
\text { potential } \\
\text { (see Tables } 3 \text { and 4) }\end{array}$ & $\begin{array}{l}\text { Habitat Classification } \\
\text { Captures attributes of washland } \\
\text { hydrology that define the type and } \\
\text { quality of existing or potential } \\
\text { habitats. From a vegetation } \\
\text { viewpoint, habitat type and quality } \\
\text { depend on } \\
\text { - duration of flooding } \\
\text { - seasonality of flooding, } \\
\text { - relative wetness of } \\
\text { washland soils } \\
\text { (see Table 2) }\end{array}$ \\
\hline
\end{tabular}

Figure 1 Analytical Framework for Washland Classification by Hydraulic and Habitat Characteristics. 
Table 1 Hydraulic classification with case study examples (see Appendix I).

\begin{tabular}{|c|c|c|c|}
\hline & \multicolumn{3}{|c|}{ Inflow } \\
\hline & Uncontrolled inflow & Fixed controlled inflow & Variable controlled inflow \\
\hline \multicolumn{4}{|l|}{ Outflow } \\
\hline $\begin{array}{l}\text { Uncontrolled } \\
\text { gravity return }\end{array}$ & $\begin{array}{l}1 \text { As river stage rises, water flows onto } \\
\text { the washland and returns to the channel } \\
\text { when the stage falls. This situation is } \\
\text { akin to a natural floodplain and is the } \\
\text { best example of on-line storage. } \\
\text { Examples include the Long Eau }\end{array}$ & $\begin{array}{l}2 \text { Water flows into the washland once } \\
\text { a flood bank is overtopped, and returns } \\
\text { to the channel in the same vicinity via a } \\
\text { flapped outfall when the stage falls. }\end{array}$ & $\begin{array}{l}3 \text { Water is let into the washland via a } \\
\text { sluice gate at the discretion of the flood } \\
\text { manager, and returns to the channel via } \\
\text { a flapped outfall when the stage falls. }\end{array}$ \\
\hline $\begin{array}{l}\text { Fixed controlled } \\
\text { gravity return }\end{array}$ & $\begin{array}{l}4 \text { This situation is unlikely to occur as } \\
\text { if water flow into the washland is } \\
\text { unimpeded return flow should also be } \\
\text { unimpeded. }\end{array}$ & $\begin{array}{l}5 \text { Water flows into the washland once } \\
\text { a flood bank or spillway is overtopped. } \\
\text { Water returns to the channel back over } \\
\text { the embankment/spillway or via a } \\
\text { flapped outfall some distance } \\
\text { downstream where there is sufficient } \\
\text { head difference for gravity flow. } \\
\text { Examples include Coombe Hill. }\end{array}$ & $\begin{array}{l}6 \text { Water is let into the washland via a } \\
\text { sluice gate at the discretion of the flood } \\
\text { manager, and returns to the channel via } \\
\text { a flapped outfall some distance } \\
\text { downstream where there is sufficient } \\
\text { head difference for gravity flow. }\end{array}$ \\
\hline $\begin{array}{l}\text { Variable } \\
\text { controlled } \\
\text { return: } \\
\text { sluices/pumps }\end{array}$ & $\begin{array}{l}7 \text { This situation is unlikely to occur as } \\
\text { if water flow into the washland is } \\
\text { unimpeded return flow should also be } \\
\text { unimpeded. (water could enter via a } \\
\text { flapped gate that prevents return flow } \\
\text { and is then pumped back into the river, } \\
\text { but this example was not found). }\end{array}$ & $\begin{array}{l}8 \text { Water flows into the washland once } \\
\text { a flood bank is overtopped, and is then } \\
\text { pumped back into the river. Examples } \\
\text { include Beckingham Marsh. }\end{array}$ & $\begin{array}{l}9 \text { Water flows into the washland when } \\
\text { a control on the river is closed (at the } \\
\text { discretion of the flood manager), and } \\
\text { returns to the channel once the control } \\
\text { is re-opened. Examples include } \\
\text { Harburtonford and the Leigh Barrier. }\end{array}$ \\
\hline
\end{tabular}

contribute to flood management in the desired manner. For example, a washland that fills early on the rising limb of the flood hydrograph may reach its maximum storage capacity before the peak discharge is reached. This may produce a reduction in the volume, and delay the timing, of the downstream flood peak, but may not significantly affect the peak discharge. Similarly, a washland that does not drain down quickly enough after a flood event may not provide significant storage in a subsequent event - or may even exacerbate the flood risk [10]. The strategic value of washlands in catchment-scale flood risk management, therefore, depends on the timing of the filling and subsequent drainage of the wetland in relation to the design flood hydrograph and the degree of control that the flood manager has over the timing.

The second stage, referred to as the Habitat Classification (Table 2), captures those attributes of washland hydrology that critically define the type and quality of the habitat that exists or can be created. For vegetation, habitat type depends to some extent on the depth, duration and seasonality of flooding. The tolerances of individual wetland species to flood events has received considerable attention in the ecological literature and a number of authors have quantified both their physiological tolerance [14-16] and their ecological niche [17]. However, the vegetation composition of washlands is often more dependent on the soil hydrology [18] between flood events than on the nature of the events themselves. Attempts have been made to describe the ecological niche of plant communities with respect to the soil's hydrological regime [19, 20]. For wildlife, non-hydrological features such as scale, freedom from human disturbance, and connectedness with migratory pathways are also important [21-25]. The hydrological preferences of vegetation types used in the Habitat Classification presented in Table 2 draw on data from a large scale study undertaken across the floodplains of England during the period 1992-2002 [26, 27]. The classification makes no attempt to sub-divide categories on the basis of nutrient availability, though this will be an important consideration when selecting appropriate target communities at a specific location [28, 29].

In the UK, as in many other European countries, priorities and funding for the protection and enhancement of biodiversity focus on the implementation of national Biodiversity Action Plans (BAPs). The UKBAP [30] feature a number of wetland species (birds, mammals, invertebrates, plants) and wetland habitats that may be compatible with washlands (e.g. lowland meadows, coastal and floodplain grazing marsh, wet woodland) with specific targets for conservation or expansion of the named habitats. It is important, therefore, that the link is made between this policy framework and the design and implementation of washlands that would support target habitats. The classification can define the habitat potential of a given water regime, or the change in water regime that may be needed to achieve a particular change in habitat potential.

Although there is no direct link between the Hydraulic and the Habitat classifications, it is possible to adopt interventions 
Table 2 Habitat classification of washlands by flood and soil water regimes and related habitat types.

\begin{tabular}{|c|c|c|c|c|c|c|}
\hline & \multicolumn{3}{|c|}{ Winter flooding only } & \multicolumn{3}{|c|}{ Flooding at any time of year } \\
\hline & Rapid soil drainage & $\begin{array}{l}\text { Moderate soil } \\
\text { drainage }\end{array}$ & Slow soil drainage & Rapid soil drainage & $\begin{array}{l}\text { Moderate soil } \\
\text { drainage }\end{array}$ & Slow soil drainage \\
\hline $\begin{array}{l}\text { Short } \\
\text { duration } \\
\text { flooding }\end{array}$ & $\begin{array}{l}1 \\
\text { Arable } \\
\text { Hay meadow } \\
\text { Pasture } \\
\text { Alder Woodland }\end{array}$ & $\begin{array}{l}2 \\
\text { Flood meadow } \\
\text { Pasture } \\
\text { Alder Woodland }\end{array}$ & $\begin{array}{l}3 \\
\text { Flood meadow } \\
\text { Inundation pasture } \\
\text { Alder Woodland }\end{array}$ & $\begin{array}{l}4 \\
\text { Water meadow } \\
\text { Pasture } \\
\text { Alder Woodland }\end{array}$ & $\begin{array}{l}5 \\
\text { Inundation pasture } \\
\text { Alder Woodland }\end{array}$ & $\begin{array}{l}6 \\
\text { Inundation pasture } \\
\text { Rush pasture } \\
\text { Swamp } \\
\text { Willow carr }\end{array}$ \\
\hline $\begin{array}{l}\text { Medium } \\
\text { duration } \\
\text { flooding }\end{array}$ & $\begin{array}{l}7 \\
\text { Hay meadow } \\
\text { Pasture } \\
\text { Alder Woodland }\end{array}$ & $\begin{array}{l}8 \\
\text { Flood meadow } \\
\text { Pasture } \\
\text { Alder Woodland }\end{array}$ & $\begin{array}{l}9 \\
\text { Flood meadow } \\
\text { Inundation pasture } \\
\text { Swamp } \\
\text { Willow carr }\end{array}$ & $\begin{array}{l}10 \\
\text { Pasture } \\
\text { Rush pasture } \\
\text { Willow carr }\end{array}$ & $\begin{array}{l}11 \\
\text { Inundation pasture } \\
\text { Rush pasture } \\
\text { Swamp } \\
\text { Willow carr }\end{array}$ & $\begin{array}{l}12 \\
\text { Inundation pasture } \\
\text { Rush pasture } \\
\text { Swamp } \\
\text { Willow carr }\end{array}$ \\
\hline $\begin{array}{l}\text { Long } \\
\text { duration } \\
\text { flooding }\end{array}$ & $\begin{array}{l}13 \\
\text { Flood meadow } \\
\text { Pasture } \\
\text { Willow carr }\end{array}$ & $\begin{array}{l}14 \\
\text { Inundation pasture } \\
\text { Rush pasture } \\
\text { Swamp } \\
\text { Willow carr }\end{array}$ & $\begin{array}{l}15 \\
\text { Inundation pasture } \\
\text { Rush pasture } \\
\text { Swamp } \\
\text { Willow carr }\end{array}$ & $\begin{array}{l}16 \\
\text { Swamp } \\
\text { Willow carr }\end{array}$ & $\begin{array}{l}17 \\
\text { Swamp } \\
\text { Reedbed }\end{array}$ & $\begin{array}{l}18 \\
\text { Swamp } \\
\text { Reedbed }\end{array}$ \\
\hline
\end{tabular}

Note:

Soil drainage is a function both of soil conductivity and drainage infrastructure.

Rapid soil drainage $=$ Following inundation, water table typically falls by $>30 \mathrm{~cm}$ in $<10$ days in winter.

Moderate soil drainage $=$ Following inundation, water table typically falls by $>30 \mathrm{~cm}$ in $<30$ days in winter.

Slow soil drainage $=$ Water table does not fall below $30 \mathrm{~cm}$ following an inundation event in winter until late April

Short duration of surface water: typically 3 days per event.

Medium: Typically less than 2 weeks per event.

Long: Typically more than two weeks per event.

to "engineer" and manage particular flooding and soil wetness regimes, and thereby enhance habitat potential. These are contained in a "Menu of Interventions". Some interventions are designed to change flooding regimes (Table 3), for example, through the construction of spillways to facilitate overtopping or the setback or removal of agricultural flood defences. Other interventions are designed to influence soil wetness regimes on the washland beyond the flood event (Table 4) such as through the construction of hollows to retain surface water, or changes in pumping regimes to control water levels in the arterial drainage network.

The analytical framework developed here classifies washlands according to engineering, water regime management, flood management and potential for biodiversity. This approach is "output/achievement" rather than "input/methods" driven - perceiving engineering and management options as the means by which flood management and biodiversity objectives can be met. It is important to recognise that a given washland habitat can be achieved by different intervention methods, the choice and impact of which will vary accordingly to site circumstances. The approach was used to classify the hydraulic and habitat characteristics of five selected case study sites as shown in Appendix 1. In this respect the approach draws on a mix of deductive (from the theory to observed practice) and inductive research (from observed practice to a theoretical framework). The output provides a logical framework to interpret what can be observed, and can help those who are charged with the design and promotion of washlands.

\section{Washland classification based on benefit type}

Evidence from the case studies and questionnaire surveys conducted by email of senior flood defence and conservation managers confirmed that the priority given to flood defence and biodiversity varies amongst washland sites, reflecting a mix of site characteristics, historical origins, needs and opportunities, and whether flood defence or biodiversity are perceived as the dominant interest. In this respect, it is possible to categorise washland sites into three types according to priority of purpose. These are:

Flood management washlands: Where flood management is the most important purpose and biodiversity is a secondary consideration. Biodiversity objectives can be met as long as they do not compromise flood management purposes, especially public safety and protection of the built environment.

Integrated washlands: Where flood management and biodiversity have equal consideration and management regimes are sought which enable these two objectives to be met simultaneously, for example by retaining ground wetness and some surface water for habitat without compromising flood storage. The scope for full integration of these functions needs to be identified at initial project identification and design, with water regimes and intervention measures built in and managed accordingly.

Conservation washlands: Where biodiversity is the most important purpose and flood management is a secondary consideration. 
Table 3 Menu of possible interventions to modify the frequency/duration of washland flooding and the downstream hydrograph for the benefit of biodiversity.

\begin{tabular}{|c|c|c|c|}
\hline Action & Hydraulic impact & Washland impact & In-channel impact \\
\hline $\begin{array}{l}\text { Set-back/removal of } \\
\text { embankments }\end{array}$ & Increased on-line storage & Increased area & Reduced peak stage \\
\hline $\begin{array}{l}\text { Introducing/lowering } \\
\text { spillways in banks }\end{array}$ & $\begin{array}{l}\text { Increased frequency of } \\
\text { off-line storage }\end{array}$ & $\begin{array}{l}\text { Increased frequency of } \\
\text { inundation }\end{array}$ & Reduced peak stage \\
\hline $\begin{array}{l}\text { Decreased channel } \\
\text { maintenance leading to } \\
\text { increased river and bank } \\
\text { vegetation }\end{array}$ & $\begin{array}{l}\text { Change in stage-discharge } \\
\text { relationship }\end{array}$ & $\begin{array}{l}\text { Increased frequency of } \\
\text { inundation }\end{array}$ & $\begin{array}{l}\text { Increased stage at all } \\
\text { discharges, depending on the } \\
\text { extent of vegetation }\end{array}$ \\
\hline $\begin{array}{l}\text { Creation of in-line } \\
\text { dams/sluices }\end{array}$ & $\begin{array}{l}\text { Increased back-water } \\
\text { effect }\end{array}$ & $\begin{array}{l}\text { Increased frequency of } \\
\text { inundation }\end{array}$ & Increased peak stage \\
\hline $\begin{array}{l}\text { Increased pumping/siphoning } \\
\text { into washland }\end{array}$ & Variable & $\begin{array}{l}\text { Increased frequency and } \\
\text { duration of inundation }\end{array}$ & $\begin{array}{l}\text { Reduced in-channel discharge } \\
\text { (up to capacity of washland) }\end{array}$ \\
\hline $\begin{array}{l}\text { Reduced pumping/restricted } \\
\text { gravity outflow from } \\
\text { washland }\end{array}$ & Variable & $\begin{array}{l}\text { Increased duration of } \\
\text { inundation }\end{array}$ & $\begin{array}{l}\text { Changed (reduced) } \\
\text { in-channel discharge linked to } \\
\text { the event frequency }\end{array}$ \\
\hline $\begin{array}{l}\text { Increased vegetation height } \\
\text { on floodplain }\end{array}$ & $\begin{array}{l}\text { Reduced rate of inflow } \\
\text { and outflow }\end{array}$ & $\begin{array}{l}\text { Change in duration of } \\
\text { flooding }\end{array}$ & $\begin{array}{l}\text { Increased floodplain } \\
\text { roughness. Vegetation on } \\
\text { washland may allow rapid } \\
\text { run-on but slow runoff }\end{array}$ \\
\hline Lowering of floodplain & Increased off-line storage & $\begin{array}{l}\text { Increased frequency and } \\
\text { duration of inundation }\end{array}$ & None upstream \\
\hline $\begin{array}{l}\text { Ecological flooding: retention } \\
\text { and evacuation just in time } \\
\text { for next flood }\end{array}$ & Increased off-line storage & $\begin{array}{l}\text { Controlled duration of } \\
\text { inundation for specific } \\
\text { habitats }\end{array}$ & Reduced peak stage \\
\hline
\end{tabular}

Here, the creation and management of wetland habitats are the key objectives. Flooding frequencies, depths and timings which might damage important plants and animals are to be avoided except in the most extreme events.

\section{Washland management protocols}

Management of the washlands is essential for effective flood defence and wildlife conservation. Some models already exist to describe the detailed response of vegetation to altered water management [31-33], but they tend to be specific for particular hydrological situations such as deep peats or sandy soils. They are therefore not suitable for general application to floodplain soils which are often of low permeability. In spite of a lack of quantitative guidance for floodplains, a review of management protocols for washlands with reference to flood defence, soil water control, and habitat maintenance concluded that considerable qualitative guidance does already exist [22-24]. This guidance, and supporting prescriptions, further informs the menu of interventions referred to earlier. The relevance and required detail of guidance will ofcourse vary according to the objectives of the site management and site characteristics.

\section{Financial and economic impacts on agriculture}

The impacts of washland creation on the incomes of farmers depend on prior land use, the extent of change in water regimes, and the consequences for land use, farming practices, yields and profitability. Agriculture, as for most land-engaging activities, is very sensitive to flooding above and water logging below the land surface. Estimates can be derived of the financial performance of farming under different water management regimes [34-37], and thereby the financial impacts of change associated with washland creation and management. These impacts vary considerably according to the frequency, duration, depth and, particularly the seasonality of the flood or waterlogging event.

Given that the key to integrated washland development is the maintenance of relatively wet conditions beyond the flood event, it is unlikely that this can be achieved within an arable farming regime or an intensive grassland system. Thus, the impacts on farm incomes will depend on whether the integrated washland option reduces the productivity of existing grassland systems, or switches land use to less intensive types such as extensive grass or woodland. Income loss, and the financial incentives required to encourage farmers to take up the voluntary washland option, will therefore depend on the required degree of land use change.

By way of example, in the Somerset Levels and Moors of south western England [38] income losses for farmers associated with floods of about one week during winter on grassland are relatively small, probably of the order of Euro 20/ha or so. However, where flooding and subsequent wetness involve a switch from either improved grass or cereal production to inundation grassland, annual income loss measured in terms of reduced gross margins 
Table 4 Menu of possible interventions to modify washland soil drainage conditions for the benefit of biodiversity.

\begin{tabular}{|c|c|c|c|}
\hline Action & Hydraulic impact & Washland impact & $\begin{array}{l}\text { Drainage channel impact } \\
\text { in the washland }\end{array}$ \\
\hline $\begin{array}{l}\text { Vegetation management to } \\
\text { facilitate natural retention }\end{array}$ & $\begin{array}{l}\text { Longer retention, } \\
\text { decreased peak outflow }\end{array}$ & Increased wetness & $\begin{array}{l}\text { Increased storage capacity } \\
\text { of channels within the } \\
\text { washland drainage } \\
\text { network }\end{array}$ \\
\hline Raise outflow sluices & $\begin{array}{l}\text { Water retained, reduction } \\
\text { in storage capacity }\end{array}$ & $\begin{array}{l}\text { Wetter soil, higher water } \\
\text { tables possible }\end{array}$ & Water levels raised \\
\hline $\begin{array}{l}\text { Changes in pumping } \\
\text { regime }\end{array}$ & $\begin{array}{l}\text { Controlled outflow, effect } \\
\text { on storage capacity }\end{array}$ & $\begin{array}{l}\text { Wetter soil, higher water } \\
\text { tables possible }\end{array}$ & Water levels maintained \\
\hline $\begin{array}{l}\text { Introduce hydrological } \\
\text { compartments }\end{array}$ & $\begin{array}{l}\text { Water retained, possible } \\
\text { reduction of storage } \\
\text { capacity for subsequent } \\
\text { floods }\end{array}$ & $\begin{array}{l}\text { Hydrologically isolated } \\
\text { areas, retained wet areas }\end{array}$ & $\begin{array}{l}\text { Re-routed drainage } \\
\text { channels to connect } \\
\text { hydrological } \\
\text { compartments in the } \\
\text { washland }\end{array}$ \\
\hline $\begin{array}{l}\text { Create scrapes, hollows } \\
\text { and ponds }\end{array}$ & $\begin{array}{l}\text { Holds water on the } \\
\text { floodplain, impact on } \\
\text { flood storage capacity }\end{array}$ & $\begin{array}{l}\text { Soil removed to create } \\
\text { hollows, maintained } \\
\text { wetness of site in } \\
\text { localized areas }\end{array}$ & $\begin{array}{l}\text { Scrapes and ditches } \\
\text { connected to the drainage } \\
\text { channel system to } \\
\text { integrate whole drainage } \\
\text { system }\end{array}$ \\
\hline $\begin{array}{l}\text { Modify ditches, including } \\
\text { control structures }\end{array}$ & $\begin{array}{l}\text { Control drainage of } \\
\text { surface water, possibly } \\
\text { increased storage }\end{array}$ & $\begin{array}{l}\text { Controlled water table } \\
\text { levels }\end{array}$ & $\begin{array}{l}\text { Changed water regimes in } \\
\text { washland soils, possibly } \\
\text { increased ditch network }\end{array}$ \\
\hline Introduce subsurface pipes & $\begin{array}{l}\text { Water drained through soil } \\
\text { profile via pipes or } \\
\text { provision of sub-irrigation }\end{array}$ & $\begin{array}{l}\text { Controlled water table } \\
\text { levels }\end{array}$ & $\begin{array}{l}\text { Water levels in washland } \\
\text { channels lowered or raised } \\
\text { to provide drainage or } \\
\text { sub-irrigation respectively }\end{array}$ \\
\hline $\begin{array}{l}\text { Increase ditch roughness, } \\
\text { possibly through reduced } \\
\text { maintenance }\end{array}$ & $\begin{array}{l}\text { Flow rate reduced and } \\
\text { increased water held on } \\
\text { washland }\end{array}$ & Water table levels raised & $\begin{array}{l}\text { Increased vegetation in } \\
\text { channels as part of a } \\
\text { natural outflow control } \\
\text { system }\end{array}$ \\
\hline
\end{tabular}

can be as much as Euro 450/ha. However, where whole farms can adopt less intensive systems, income losses are about Euro 150/ha due to savings in overhead costs especially those associated with labour, machinery and equipment and possibly buildings. These income losses indicate the scale of compensation payments that might be required to encourage adoption of wetland options by farmers. At the present time, payments to farmers in the area range from about Euro 160 to over Euro 600/ha/year according to the degree of compliance with agri-environment conditions.

Economic analysis of washland creation [39,37,40], which strips out the value of subsidies from commodity prices, shows that, at current levels of government support to agriculture, there can be advantage to the national economy from moving to extensive washland farming systems. Furthermore, agri-environment payments to farmers are indicative of society's willingness to pay for environmental goods (although the actual level of environmental payment is influenced by the degree of support to agricultural production with which they have to compete). Registering these as a benefit of washland development increases the economic value of the washland option. Given the opportunity to achieve economic and environmental benefits through integrated washland creation [41, 42], and through targeted support to help sustain incomes to the farming community, it would appear in the public interest to redirect funding from agricultural support and flood defence into flood storage and washland creation.

The case studies include situations where access to agrienvironmental payments encouraged farmers to adopt the washland option. On the Beckingham Marsh Scheme (Appendix 1), arable land has reverted to wet grassland under management agreements between farmers and a conservation organisation. The Long Eau scheme involves the setback of agricultural flood defences to reconnect the flood plain to the river channel and the reversion of arable land to wet grassland supported by payments to occupiers under the agri-environment Countryside Stewardship Scheme.

\section{Administrative and funding arrangements for washland development}

Arrangements for administration and funding of washlands critically affect the feasibility and eventual success of an integrated 
Table 5 Administrative and Related Funding Options for Washland Management.

\begin{tabular}{ll}
\hline Option & Strengths \\
\hline Land Purchase and transfer of & Good chance of delivering flood storage \\
ownership to authority or trust with & and environmental objectives \\
occupation by owners or tenants & Up-front funding \\
& Funded under capital budgets \\
& Provide exit route for some farmers
\end{tabular}

Easement: one-off payment to compensate existing land owners for increased flood risk with payment according to the degree of risk, typically ranging from $40 \%$ to $100 \%$ of land value

Annual Payments linked to management agreements to compensate for income loss and/or environmental enhancement. Commonly used as part of agri-environmental schemes

Lease-back: transfer of ownership or control to authority or trust with tenancies to previous owners
Focus on flood defence aspects

Suited to compensating risk of infrequent flood events

Attractive to flood defence agency: one-off payment funded out of capital expenditure

Potential to deliver range of objectives: social, economic and environmental

Maintain farmer and community links with land

Farmer familiarity with payment mechanism

Integrate with agri-environment schemes

Can be adjusted over time according to objectives/circumstances

Ability to focus on scheme objectives

Partnership approach

Farmers/community engaged in

implementation

Diverse "partner" funding sources

\section{Weaknesses}

Risk of reduced ties to farming community

Problems of attracting and negotiating tenants

Difficult to arrange purchases in large blocks

Relies on voluntary participation, unless made compulsory

Less suited to significant changes in flood risk

Less suited to delivering environmental enhancement

Inflate land prices, encourage subletting Mixed success of agri-environment schemes

Participation dependent on "incentives"

Expensive, dependent on 'revenue'

budgets

Increases farmer dependency

Inadequate longevity of funding

regimes discourages farmer participation

Administratively and legally

complicated to establish

Reluctance to transfer assets until

scheme proven

Requires clear community of interest

amongst participants approach to washland development. The main options (Table 5) are those associated with land purchase by an organisation responsible for washland management, the purchase of flood easements (whereby an entitlement to flood is purchased from the landowners), the use of annual management agreements and lease back of the purchased land to the previous owners.

Although land purchase is an option for all washlands, the choice of most suitable method appears to vary according to the dominant purpose of washland management, and the degree of control required by the responsible organisation. Easements have been commonly used for flood management washlands, whereas annual agri-environment payments have been used mainly for conservation washlands.

The case studies showed that a mixture of administrative arrangements is often needed to accommodate the diversity of circumstance and practice amongst and within washlands. Flood managers and conservationists expressed preference for the land purchase option because this is perceived to maximise the degree of management control, whether for flood management or biodiversity. In many cases, purchased land has been subsequently let to tenant occupiers subject to conditions on use, often at very low rents.
Current reform of agricultural policy, together with obligations to implement EU environmental regulations such as the Water Framework Directive, the Habitats Directive and the proposed Soils Directive, provide an opportunity to bring together policy objectives and mechanisms that have hitherto been fragmented and occasionally in conflict. In the English case, the new Environmental Stewardship scheme to be introduced in 2005 [43] may include an option for inundation washland with annual payments over a 20 year period. The forthcoming introduction of a single farm payment regime in England [44], whereby farmers receive annual income support which is "decoupled" from production but requires compliance with good farming practice, could, combined with other incentives, further encourage voluntary take up of the washland option. Although these examples relate to the English case, there are similar challenges and opportunities across Europe and beyond as Government's grapple with agricultural reform and environmental regulation.

\section{Achieving integrated washlands}

Although it was apparent that flood defence managers and conservation officers perceive potential synergy between flood 
management and biodiversity in washlands, conflicts of interest can arise with respect to the duration and timing of flooding, and the management of soil wetness beyond the flood event period. The questionnaire survey and workshop revealed confirmed that flood managers usually want to get water away quickly to maximise storage for subsequent events whilst conservationists often wish to retain standing water or soil wetness once flooding is over.

A simple classification, such as that proposed here, may facilitate the discussion between the different interest groups. Existing methods of integrated assessment such as the functional assessment of wetlands [45] have not been widely adopted, partly because they may require very detailed, site-specific information, which cannot be gathered within the resources generally available to investigations of this type. There is some overlap between the classification method proposed here and the functional assessment of wetlands procedure, but the latter has no direct parallel to the interventions menu.

Within a given flood regime, which may be largely dictated by flood management requirements, water table management beyond the flood period is probably the most critical factor which determines habitat potential. A site-specific water level management plan is essential to deliver biodiversity benefits. Designs should provide adequate flood storage capacity, allowing some surface water to be held on the site after the floodwaters recede and retaining high ground water levels for biodiversity benefit. Opportunities for biodiversity are likely to be limited on infrequently flooded washland sites where rapid drainage of soil water allows arable farming. However species-rich grasslands, such as floodplain meadows (Alopecurus pratensis-Sanguisorba officinalis grassland) and water meadows (Calthion grasslands), require short duration flooding followed by rapid soil drainage, which is fully compatible with flood management preferences.

The rather limited evidence to date in England shows that best results are achieved where biodiversity enhancement is built into initial design of the washland project, rather than treated as an afterthought. Engaging all stakeholders in this process is critical. The integrated washland option can be a more challenging but potentially more sustainable solution to flood management problems than the conventional flood defence approach.

With respect to funding, flood managers and conservation managers appear to agree that although flood defence budgets cannot be expected to be a major source of funds for biodiversity enhancement, some limited allocation of funding for biodiversity within flood defence budgets should be possible. It is likely however, that designated funds for biodiversity, linked to specific outcomes, are required if the development of integrated washlands is going to happen to the scale possible or desirable.

\section{Conclusions}

Taking a broad definition of washlands, a classification by hydraulic, habitat, and dominant purpose can provide an improved understanding of the relationship between flood and water level management regimes and biodiversity. The classification system and evidence from case study sites confirm that biodiversity gain depends very much on the management of water regimes beyond the flood period. The classification system can help to determine, for given local conditions, the potential for habitat creation under a given water regime and the range of interventions that can be used to manipulate washland water regimes in pursuit of particular habitat objectives. Classification by benefit type can help to identify appropriate funding sources, whether these are designated mainly for conservation, for flood risk management, and/or support to farm incomes.

While there are some conflicts of interests between the objectives of flood management, nature conservation and farming, there is considerable opportunity to achieve synergy. There is also an opportunity to "join-up" of policy and funding mechanisms that hitherto have been fragmented and have discouraged integration.

In the English context, it is strongly recommended that responsible agencies work together to develop and test an integrated approach to washland management within selected catchments/sub-catchments where it is perceived the approach can offer potential advantage. This will provide much needed experienced-based guidance on how to identify, prepare and implement a programme for integrated washland development. It will also help to "contribute to the mitigation of the effects of floods" required by the Water Framework Directive in a way which is compatible with the ecological objectives of the Directive.

\section{Acknowledgement}

The authors thank Defra and English Nature for their support for this work and assistance given by David Collins (Defra) and Alison Giacomelli and David Witherington (English Nature).

Appendix 1 Summary of Five English Washland Case Studies and Classification by Hydraulic and Habitat Characteristics.

\begin{tabular}{|c|c|c|c|c|c|}
\hline $\begin{array}{l}\text { Site age in years, } \\
\text { area in ha }\end{array}$ & $\begin{array}{l}\text { Washland Benefit } \\
\text { Type }\end{array}$ & $\begin{array}{l}\text { Engineering } \\
\text { solutions \& } \\
\text { Hydraulic } \\
\text { Classification type }\end{array}$ & Flooding & Vegetation/ landuse & $\begin{array}{l}\text { Biodiversity and } \\
\text { Habitat Classification } \\
\text { Cell }\end{array}$ \\
\hline $\begin{array}{l}\text { Beckingham Marshes } \\
\text { (Nottinghamshire) } \\
40 \text { years, with recent } \\
\text { wetland enhancement } \\
1000 \text { ha }\end{array}$ & Flood Management & $\begin{array}{l}\text { Pumps, Sluice gate, } \\
\text { drainage ditches, } \\
\text { embankments. } \\
\text { Type } 8\end{array}$ & $\begin{array}{l}2-3 \text { days duration, } \\
1 \text { in } 10 \text { years Winter }\end{array}$ & Arable & $\begin{array}{l}\text { Enhancements aimed } \\
\text { at waterfowl } \\
\text { Cell: } 1\end{array}$ \\
\hline
\end{tabular}


Appendix 1 (Continued)

\begin{tabular}{|c|c|c|c|c|c|}
\hline $\begin{array}{l}\text { Site age in years, } \\
\text { area in ha }\end{array}$ & $\begin{array}{l}\text { Washland Benefit } \\
\text { Type }\end{array}$ & $\begin{array}{l}\text { Engineering } \\
\text { solutions \& } \\
\text { Hydraulic } \\
\text { Classification type }\end{array}$ & Flooding & Vegetation/ landuse & $\begin{array}{l}\text { Biodiversity and } \\
\text { Habitat Classification } \\
\text { Cell }\end{array}$ \\
\hline $\begin{array}{l}\text { Leigh Barrier (Kent) } \\
30 \text { years } 278 \text { ha }\end{array}$ & Flood Management & $\begin{array}{l}\text { Embankments, } \\
\text { radial gates, } \\
\text { scrapes. } \\
\text { Type } 9\end{array}$ & $\begin{array}{l}3-4 \text { days duration, } \\
2 \text { times per year } \\
\text { Winter }\end{array}$ & $\begin{array}{l}\text { Pasture and small } \\
\text { areas of woodland. }\end{array}$ & $\begin{array}{l}\text { Increase general } \\
\text { biodiversity via } \\
\text { excavation of scrapes. } \\
\text { Cell: } 8\end{array}$ \\
\hline $\begin{array}{l}\text { Harbertonford (Devon) } \\
3 \text { years } 3.5 \text { ha }\end{array}$ & $\begin{array}{l}\text { Integrated Flood } \\
\text { Management and } \\
\text { Conservation }\end{array}$ & $\begin{array}{l}\text { Dam, sluices, } \\
\text { scrapes, vegetation } \\
\text { planting } \\
\text { Type } 9\end{array}$ & $\begin{array}{l}2 \text { days duration } \\
\text { Designed to retain } \\
1: 10 \text { year event } \\
\text { Winter and Summer }\end{array}$ & $\begin{array}{l}\text { Woodland and } \\
\text { lowland wet } \\
\text { grassland }\end{array}$ & $\begin{array}{l}\text { Increase general } \\
\text { biodiversity by } \\
\text { recreating natural } \\
\text { washland. } \\
\text { Cell: } 11\end{array}$ \\
\hline $\begin{array}{l}\text { Long Eau } \\
\text { (Lincolnshire) } 7 \text { years } \\
\text { ( } 25 \text { years since original } \\
\text { defences) } 15 \text { ha }\end{array}$ & Conservation & $\begin{array}{l}\text { Setback } \\
\text { embankments. } \\
\text { Type } 1\end{array}$ & $\begin{array}{l}\text { 3-4 days duration, } \\
\text { 3-4 times per year. } \\
\text { Winter }\end{array}$ & Pasture & $\begin{array}{l}\text { Increase general } \\
\text { biodiversity via } \\
\text { grassland } \\
\text { management. } \\
\text { Cell: } 8\end{array}$ \\
\hline $\begin{array}{l}\text { Coombe Hill } \\
\text { (Gloucestershire) } \\
30 \text { years, with later } \\
\text { extension to wetland } \\
\text { areas } 650 \text { ha }\end{array}$ & Conservation & $\begin{array}{l}\text { Non return valve, } \\
\text { embankments, } \\
\text { ditches. } \\
\text { Type } 5\end{array}$ & $\begin{array}{l}\text { Highly variable } \\
\text { duration Annually } \\
\text { Winter }\end{array}$ & $\begin{array}{l}\text { Pasture/ hay } \\
\text { meadow }\end{array}$ & $\begin{array}{l}\text { Enhancements aimed } \\
\text { at waterfowl } \\
\text { Cell: } 14\end{array}$ \\
\hline
\end{tabular}

\section{References}

1. Morris, J. (1992). “Agricultural Land Drainage, Land Use Change and Economic Performance: Experience in the UK," Land Use Policy, 3(9), 185-198.

2. DEFRA (2002). Farming and Food's Contribution to Sustainable Development. Economic and Statistical Analysis. Department for Environment, Food and Rural Affairs, London, Defra Publications.

3. Wise Use of Floodplains (2002). EU Wise Use of Floodplains Project, http://www.floodplains.org.uk.

4. Morris, J., Hess, T.M., Gowing, D.J.G., LeEDSHARrison, P.B., BANNISTER, N., VIVASH, R.M.N. and WADE, M. (2004). Integrated Washland Management for Flood Management and Biodiversity. English Nature Research Report Number 598, English Nature, Peterborough.

5. Environment Agency, Department for Environment, Food and Rural Affairs and National Assembly for Wales (2004). Catchment Flood Management Plans; Guidelines. Volume 1 Policy Guidance (4th Draft). http://environment-agency.gov. uk/commondata/acrobat/cfmpvoguidfour_747050.pdf

6. Morris J., Hess T., Gill A., Howsam P. and White S. (2004). The water framework directive and flood management - a missed opportunity? Proceedings of $39^{\text {th }}$ Defra Flood and Coastal Management Conference, June $28^{\text {th }}$ July $1^{\text {st }}$ 2004. http://www.defra.gov.uk/environ/fcd/conference/ abs39.htm\#04-3

7. Foresight (2003). Foresight Flood and Coastal Defence Project: An Analysis of Future Risk of Flooding and Coastal Erosion for the UK Between 2030-2100. Office of
Science and Technology, Department of Trade and Industry, London.

8. Defra (2004a). Making Space for Water: Developing A New Government Strategy for Flood and Coastal Erosion Risk Management In England. Department for Environment, Food and Rural Affairs. Defra Publications, London.

9. Pearsall, J. (2001). New Oxford Dictionary of English. Oxford University Press.

10. English Nature, Environment Agency, Department for Environment, Food and Rural Affairs and Forestry Commission (2002). Wetlands, Land Use Change and Flood Management (A Joint Statement). English Nature, Peterborough and Department for Environment, Food and Rural Affairs, London.

11. RPA (2001). Sustainable Flood defence. The Case for Washlands. Risk and Policy Analysis, Loddon, Norfolk. English Nature Research Report 406. English Nature, Peterborough.

12. Rutter, E.J. and Engstrom, L.R. (1964). Hydrology of Flow Control. Part III. Reservoir Regulation. In Handbook of Applied Hydrology. Ed. Ven Te VChow. McGraw-Hill, New York.

13. Bullock, A. and Acreman, M. (2003). "The Role of Wetlands in the Hydrological Cycle," Hydrology and Earth System Sciences, 7(3), 358-389.

14. Blom, C.W.P.M. and VoeseneK, L.A.C.J. (1996). "Flooding: The Survival Strategies of Plants," Trends in Ecology and Evolution, 11, 290-295.

15. Vervuren, P.J.A., Blom, C.W.P.M. and DE Kroon, H. (2003). "Extreme Flooding Events on the Rhine and the Survival and Distribution of Riparian Plant Species," Journal of Ecology, 91, 135-146. 
16. VAN ECK W.H.J.M., VAN DE STEEG, H.M., BLOM, C.W.P.M., and DE KROON. H. (2004). "Is Tolerance to Summer Flooding Correlated with Distribution Patterns in River Floodplains?" A comparative study of 20 terrestrial grassland species, OIKOS, 107, 393-405

17. KedDy, P.A. (1984). "Plant Zonation on Lakeshores in Nova-Scotia - a test of the Resource Specialization Hypothesis," Journal of Ecology, 72, 797-808.

18. Youngs, E.G., LEEDS-HARRISON, P.B. and ChAPMAN, J.M. (1989). "Modelling the Water-Table Movement in Flat Low Lying Lands," Hydrological Processes, 3, 301-315.

19. Silvertown, J., DodD, M.E., Gowing, D.J.G. and MounTFORD, J.O. (1999). "Hydrologically Defined Niches Reveal a Basis for Species Richness in Plant Communities," Nature, 400, 61-63.

20. RunhaAr, J., Witte, J.P.M. and Verburg, P.H. (1997). "Ground-Water Level, Moisture Supply, and Vegetation in the Netherlands," Wetlands, 17, 528-538.

21. Thomas, G.J. (1982). "Autumn and Winter Feeding Ecology of Waterfowl at the Ouse Washes, England," Journal of Zoology, London, 197, 131-172.

22. Ward, D., Holmes, N. and Jose, P. (1994). The New Rivers and Wildlife Handbook. Sandy, Bedford, RSPB, NRA, Wildlife Trust.,

23. Benstead, P., Drake, M., José, P., Mountford, O., Newbold, C. and TreweEK, J. (1997). The Wet Grassland Guide: Managing Floodplain And Coastal Wet Grasslands For Wildlife. Sandy, Bedford, RSPB, English Nature and ITE.

24. Benstead, P., José, P., Joyce, C. and Wade, P.M. (1999). European Wet Grassland: Guidelines for Management and Restoration. Sandy, RSPB,

25. Buisse, A., CoOps, H., Staras, M., Jans, L., VAB GeEst, G., Grifts, R., Ibelings, B., Oosterberg, W. and RoOzEN, C. (2002). "Restoration Strategies for River Floodplains Along Large Lowland Rivers in Europe," Freshwater Biology, 47, 889-907.

26. Gowing, D.J.G., Youngs, E.G., Gilbert, J.C. and SPOOR, G. (1998). Predicting the Effect of Change in Water Regime on Plant Communities, in Hydrology in a Changing Environment, Volume I. Wheater, H. and Kirby, C. (eds.), John Wiley and Sons, Chichester, pp. 473-483.

27. Gowing, D.J.G., Lawson, C.S., Youngs, E.G., Barber, K.R., Rodwell, J.S., Prosser, M.V., Mountford, J.O. and SPOOR, G. (2002). The Water Regime Requirements and the Response to Hydrological Change of Grassland Plant Communities. Project BD1310. Final Report to Department for Environment, Food and Rural Affairs, London.

28. van Oorschot, M., van GaAlen, N., Maltby, E., Mockler, N., Spink, A. and Verhoeven, J.T.A. (2000). "Experimental Manipulation of Water Levels in Two French Riverine Grassland Soils," Acta Oecologia, 21, 49-62.

29. Wassen, M.J., Peeters, W.H.M. and Venterink, H.O. (2003). "Patterns in Vegetation, Hydrology, and Nutrient Availability in an Undisturbed River Floodplain in Poland," Plant Ecology, 165, 27-43.
30. UKBAP (2003). UK Biodiversity Website. http://www. ukbap.org.uk/ [accessed 23/07/2003].

31. Gremmen, N.J.M., ReiJnen, M.J.S.M., Wiertz, J. and VAN WirduM, G. (1990). "A Model to Predict and Assess the Effects of Groundwater Withdrawal on the Vegetation in the Pleistocene Areas of The Netherlands," Journal of Environmental Management, 31, 143-155.

32. Gowing, D.J.G., SpOOR, G., MountFord, J.O. and Youngs, E.G. (1994). The Water-Regime Requirements of Lowland Wet-grassland Plants. Report to Ministry of Agriculture, Fisheries and Food, Flood and Coastal Defence Division, London.

33. VAn Ek, R., WitTe, J.P.M., RunhaAR, H. and Klijn, F. (2000). "Ecological Effects of Water Management in The Netherlands: The Model DEMNAT,' Ecological Engineering, 16, 127-141.

34. Hess, T. and Morris, J. (1988). "Estimating the Value of Flood Alleviation on Agricultural Grassland," Agriculture Water Management, 15, 141-153.

35. Dunderdale, J. and Morris, J. (1997). "The Benefits and Costs Analysis of River Maintenance,' Journal of Inst of Water and Environmental Management, 11(6), 423-430.

36. Morris, J., Gowing, D.J.G., Mills, J. and Dunderdale, J.A.L. (2000) "Reconciling Agricultural Economic and Environmental Objectives: The Case of Recreating Wetlands in the Fenland Area of Eastern England," Agriculture, Ecosystems and Environment, Elsevier Science, 79, 245-257.

37. Penning-Rowsell, E., Johnson, C., Tunstall, S., TAPsell, S., Morris, J., Chatterton, J., CoKer, A. and GreEn, C. (2003). The Benefits of Flood and Coastal Defence, Techniques and Data 2002. Flood Hazard Research Centre, Middlesex University.

38. Morris, J., BAILEy, A.P., LeEDS HARrison, P.B., LAWSON, C., Alsop, D. and Vivash, R. (2004). "Economic Dimensions of Washland Creation in England: a Case from Somerset," Journal of Farm Management, 12(1), 33-48.

39. MAFF (1999). Flood and Coastal Defence Project Appraisal Guidance: Economic Appraisal (FCDPAG3). MAFF (now Defra) Publications, London.

40. Morris, J., Vivash, R.M., Alsop, D., LaWson, C., LeEds-HARrison, P.B. and BAILEY, A.P. (2002). Economic Basis and Practicalities of Washland Creation on the Somerset Levels and Moors. Report to Wise Use of Floodplain Project, Cranfield University, Silsoe, Bedford, MK45 4DT. http://www.floodplains.org.uk/pdf/ somerset/Washlands\%20Report.pdf.

41. Turner, R., VAN DEN Bergh, J., Soderqvist, T., Berendregt, A., VAn Der StraAten, J., Maltby, E. and VAN IRLAND, E. (2000). "Ecological-Economic Analysis of Wetlands: Scientific Integration for Management Policy," Ecological Economics, 35, 7-23.

42. DE Groot, R., Wilson, M. and Boumans, R. (2002). "A Typology for the Classification, Description and Valuation 
of Ecosystem Functions, Goods and Services," Ecological Economics, 41, 393-408.

43. DEFRA (2004). English Rural Development Plan: Agrienvironment Schemes Environmental. Department for Environment, Food and Rural Affairs, London, http://www.defra. gov.uk/erdp/schemes/, accessed December 2004.

44. DEFrA (2004). Single Farm Payment Scheme. Department for Environment, Food and Rural Affairs, London, http://www.defra.gov.uk/farm/capreform/ singlepay/overview/, accessed December 2004.
45. Maltby, E., Hogan, D.V., Immirzi, C.P., Tellam, J.H. and VAN DER PEIJL, M.J. (1994). Building a new approach to the investigation and assessment of wetland ecosystem functioning, in Mitsch, W.J. (ed.), Global Wetlands: Old World and New, Elsevier, Amsterdam, pp. 637-658. 